International Journal of Business Management, Entrepreneurship and Innovation, Volume 2, Issue 3, 2020, PP 102-113, ISSN 2707-8027

IJCAB

\title{
Balanced Scorecard Perspectives and Organizational Performance: Case of Kenyatta National Hospital, Kenya
}

\author{
Joseph Yaa Karisa ${ }^{1}$, Lawrence Wainaina ${ }^{2}$
}

${ }^{1}$ School of Business, Kenyatta University, Kenya

${ }^{2}$ Department of Business Administration, Kenyatta University, Kenya

\section{ABSTRACT}

The balanced scorecard is a framework that organizations follow in aligning the organization strategy, communicate organization's mission, prioritize projects, services and products as well as monitoring and measuring the advancement towards attaining the strategic objectives or targets. The overall organizational performance of Kenyatta National Hospital is still not up to standard even though it is anticipated to established high health-care standards offered to the public so that private and public hospitals can follow. Reports have revealed that cancer, heart, and kidney patients receive delayed treatment. In addition, the hospital is said to lack enough functional specialized medical equipment as well as inadequate financial support, industrial unrests, patients overcrowding, claims of medical negligence and poor service delivery. Therefore, it a major concern to the government and other stakeholders. Based on these challenges, Kenyatta National Hospital introduced a five-year strategic plan 2013 to 2018 centred on the Balanced Scorecard approach. It was within this context that the study sought to establish the influence of balanced scorecard perspectives on organizational performance of Kenyatta national hospital. The study was guided by the following specific objectives; to find out whether focus on customer perspective, financial perspective, internal business processes perspective, learning and growth perspective influence the performance of KNH Kenya. The study was also guided by Stakeholder theory, Resource based view theory and institutional theory. The study adopted a descriptive research design with quantitative techniques. The target population for the study were 80 management staff of KNH. The sample size for the study was calculated to be 67. The study used stratified random sampling procedure and simple random sampling to recruit a sample that represented the target population. Data was collected using a pre-tested structured questionnaire to capture participants insight on balanced scorecard perspectives and the overall organizational performance. Their responses on several items were scored and the scores were used in bivariate analysis and Multiple regression analysis. Descriptive statistics like measures of central tendency were used for continuous data while frequencies were used for categorical data. The data analysis was done using SPSS version 23. These results show that financial perspective and customer perspectives focus were statistically significant predictor of organizational performance at $(p<0.05)$ while internal business process and learning and growth were not statistically significant when regressed together. An $R$ squared of 0.593 which implied that focusing on all of the balanced scorecard perspectives contributed up to $59.3 \%$ of organizational performance. The study concludes that focus on balanced scorecard perspectives have a positive influence on organizational performance. However, there are variation on the magnitude of influence among the perspective. Therefore, the balanced scorecard can be used as a strategic management tool in public facilities and not only as a measurement tool. The study recommends that KNH should continue using the balanced scorecard and other public hospitals or institutions should also adopt it. The continuous usage and new adoption of the balanced scorecard would ensure better organizational performance. 
International Journal of Business Management, Entrepreneurship and Innovation, Volume 2, Issue 3, 2020, PP 102-113, ISSN 2707-8027

[IJCAB

Key Words: Balanced Scorecard Perspectives, Financial Perspective, Customer Focus, Internal Business Process, Organizational Performance

DOI: DOI 10.35942/jbmed.v2i3.140

\section{Cite this Article:}

Karisa, J., \& Wainaina, L. (2020). Balanced Scorecard Perspectives and Organizational Performance: Case of Kenyatta National Hospital, Kenya. International Journal of Business Management, Entrepreneurship and Innovation, 2(3), 102-113. https://doi.org/10.35942/jbmed.v2i3.140

\section{Introduction}

Excellent organizational performance remains the goal of any corporation whether it's for profit or not for profit. According to Yaghoobi and Haddadi' (2016), organizational performance remains to be the main measure and indicator for attaining organizational objectives and goals. Hence, a good understanding of things that influence the performance of organizations is crucial for any manager globally. There are several key performance indicators for good performance in the healthcare sector. The major indicators are; increased patients satisfaction, reduction of Hospitalacquired infections, decreased mortality rates, increased revenue collection, new products or services introduction, employee satisfaction and reduced professional misconduct (Yaghoobi \& Haddadi, 2016). Continuous transformations in the business environment has affected health care organizations throughout the world to seek new management tools and systems that will improve and sustain organizational performance. According to Gonzalez-Sanchez, et al (2017) hospitals used to operate in a stable business with less competition unlike today, as a result, new trends have emerged in the health care sector by practicing strategic management and adoption of strategic management tools so as to help these hospitals to succeed in a competitive market.

Yaghoobi and Haddadi' (2016) in their study stated that the balanced scorecard is a strategic management tool which has been adopted by many organizations around the world to improve and maintain organizational performance. Similarly, the Bain and Company 2011 survey report of management tools and trends indicates that the balanced scorecard has been in the top ten for decades and it has high satisfaction rates globally (Rigby \& Bilodeau, 2011). In addition, the recent Bain and Company guide of 2015 show that balanced scorecard has transformed and management use it to update or clarify business's strategy, tie strategic objectives to firm's annual budgets as well as long-term goals, track the main business strategy elements, incorporation of strategic objectives in the process of resource allocation, performance comparison of geographically different business units, facilitation of organizational change and increase corporate strategy and vision understanding within the company (Rigby, 2015). These uses are anticipated to ultimately result in superior and sustained organizational performance. The importance of adopting a balanced scorecard to help in achieving better organizational performance is evidenced by the numerous studies done globally and locally (Yongvanich \& Guthrie (2009); Gurd and Gao (2007); Musyoki (2015); Marete (2015); Gacheri (2011)).

The need for more studies on the influence of balanced scorecard perspectives and performance of organizations is required to evaluate its application. Numerous organizations have embraced the balanced scorecard usage in Kenya (Gacheri, 2011). One of the organizations is Kenyatta National Hospital which has a 2013 to 2018 strategic plan that is centred on a Balanced Scorecard framework. This strategic plan tries to improve on the achievements attained in the preceding 
International Journal of Business Management, Entrepreneurship and Innovation, Volume 2, Issue 3, 2020, PP 102-113, ISSN 2707-8027

\section{[IJCAB}

strategic plans. Hence, this study seeks to establish whether balanced scorecard perspectives influence the performance of Kenyatta National Hospital. Kenyatta National Hospital is located in Nairobi Kenya. The hospital's third Strategic Plan 2013- 2018 indicates that the hospital is one of the oldest and largest referral Hospitals in East Africa, with a 2,000 bed capacity and more than 6,000 staff members. In addition, the hospital serves 500,000 outpatients and 70,000 inpatients on average annually. Founded in 1901 as Native Civil Hospital which was later renamed as King George VI Hospital in 1952, and after independence, it was renamed again as Kenyatta National Hospital. The Hospital sits on 45.7 hectares of land and houses KMTC and the University of Nairobi's School of Medicine and other government agencies.

Patients from Central and Southern Africa and the Great Lakes Region are offered quality specialized health care services that include renal services (including kidney transplantation), ophthalmology (including cornea transplant), critical care services, neurosurgery, open heart surgery, burns management, reconstructive surgery, orthopedic surgery, oncology, newborn services, and palliative care, and many more. Kenyatta National Hospital just like other public institutions in Kenya is not for profit making and it has continuously faced by many challenges ranging from poor service delivery, inadequate funding from the government, lack of equipment's, industrial unrests, weak referral system, increase in disasters and accidents, emerging as well as re-emerging diseases and poor performance measurement systems. These challenges have affected the performance of the hospital leaving the clients and other stakeholders complaining about quality patient care which is the core business of the hospital. Based on these challenges and poor organizational performance, Kenyatta National Hospital developed its third strategic plan for the year 2013 to 2018 as it adds on the achievements made in the earlier strategic plans. In contrast with the previous strategic plans, the current strategic plan of 2013 to 2018 is centred on the Balanced Scorecard framework. After the implementation of this strategic plan, a need arises to carry out a study to establish how the balanced scorecard perspectives influenced Kenyatta National Hospital's organizational performance.

\section{Statement of the problem}

$\mathrm{KNH}$ is expected to set very high health-care standards to the public to be emulated by other public hospitals as well as private hospitals. Since its establishment many decades ago there has been several studies and reports claiming that the overall organizational performance of Kenyatta National Hospital is still not up to standard (Wambui 2013; Performance Audit Report 2012 ). As a result, this problem has become a major concern to the government and other stakeholders. The Auditor-General's Performance Audit Report on Specialized Healthcare Delivery at KNH (2012) revealed that there is no satisfactory service delivery to the public, for instance, cancer, heart and kidney patients receive delayed treatment. New patients wait for over two months at the Cancer Treatment Centre to see a clinical specialist. The report further states that there are shortages of specialized medical equipment, ward space, specialists, medical supplies, among others. To help counter these challenges Kenyatta National Hospital implemented several strategic plans so as to improve and sustain its organizational performance. Now having completed the implementation of 2013 to 2018 strategic plan which was centred on the Balanced Scorecard approach; the influence of balanced scorecard perspectives on performance of Kenyatta National Hospital is unknown and unpublished.

Considering the importance of the health care sector as a driving force for the Kenyan economy, there is a need to establish how balanced scorecard perspectives influence the performance of 
International Journal of Business Management, Entrepreneurship and Innovation, Volume 2, Issue 3, 2020, PP 102-113, ISSN 2707-8027

\section{[IJCAB}

Kenyan health care organizations. In addition, the understanding of balanced scorecard uses in developing economies is needed (Bobe, Mihret, \& Obo, 2017). It is within this context that this research seeks to establish how balanced scorecard perspectives influence Kenyatta National Hospital's organizational performance. Literature search reveled limited information about the influence of balanced scorecard perspectives on organizational performance in public health care institutions in Kenya. For instance, Marete (2015) conducted a study on the influence of balanced scorecard perspective in the education sector. Although, Marete (2015) study focused on institutions of higher learning, variation in different economic sectors might exist hence the need to conduct a similar study in the health sector.

In a similar study conducted on higher institution of learning at the University of Nairobi (UoN), Kenya Science Campus by Seth A. \& Oyugi L, (2013) found a positive relationship between the balanced scorecard perspectives and organizational performance. The study will focus on the health sector. In addition, Ondieki (2017) conducted a cross-sectional descriptive study to assess balanced scorecard effects on organizational performance at Kenya Bureau of Standards (KEBS) and found that balanced scorecard perspectives have a positive effect on organizational performance. The current study will focus on a state-owned corporation but in a different sector and it will target the top, middle and lower levels management employees. Furthermore, Tonkei, (2016) conducted a study at the National Hospital Insurance Fund, Kenya to to establish whether balanced scorecard influences employee's behaviors and attitudes such as job satisfaction. This study focused on the employees while the current study will focus on organizational performance. This study will bridge the knowledge gap regarding the relationship between balanced scorecard perspective and organizational performance in public health institution.

\section{Objective of Study}

The general objective of study is to establish the influence of balanced scorecard perspectives on organizational performance of Kenyatta National Hospital, Kenya.

Specific objectives were:

i. To establish whether a focus on the financial perspective has an influence on the organizational performance of KNH Kenya.

ii. To establish whether a customer focus perspective influences KNH's organizational performance.

iii. To assess whether focusing on internal business process perspective influences KNH's organizational performance.

iv. To find out focusing on growth and learning perspective has an influence on KNH's organizational performance.

\section{Theoretical review}

The theories discussed in this chapter are resource-based view, institutional theory and the Stakeholder theory. The discussion and the relationship of these theories to the study variables are discussed below.

\subsection{Resource-Based View theory}

The resource-based view (RBV) theory is a managerial approach that managers use to achieve sustainable competitive advantage. This managerial framework emerged in the 1980s and 1990s through the works of Wernerfelt, B, Barney, J and others (Wernerfelt, 1984; Barney, 1996). The 
International Journal of Business Management, Entrepreneurship and Innovation, Volume 2, Issue 3, 2020, PP 102-113, ISSN 2707-8027

\section{IIJCAB}

resource-based view (RBV) theory perceives firm resources as crucial to excellent organizational performance. Therefore, when a resource within an enterprise shows value, rarity, imitability, organization (VRIO) features, then it empowers the firm to attain sustainable competitive advantage. The theory argues that firms should focus or look internally to see areas of competitive advantage rather than watching outside for it. In addition, resources can be tangible or intangible, with tangible resources coffering little advantage than intangible resources (Barney, 2012). From this theory, it can be hypothesized that when an organization acquires or develop valuable, rare and imitable resources by focusing on its finances, internal business processes, internal customers, learning and innovations of its staff then the organization may gain competitive advantage resulting into improved organizational performance. This theory, therefore, anchors both predictor variables and the outcome variable.

\subsection{Stakeholder Theory}

Stakeholder theory is a theory that tries to address the moral issues, values and business ethics in managing an organization. This theory emerged in the 1980s through the works of the organizational theorist Ian Mitroff and by philosopher and professor of business administration R. Edward Freeman (Mitroff, 1984; Freeman, 2010). A stakeholder is anyone who has an interest in an organization or project or any group or individual who can be impacted by an outcome of an organization or project. The theory tries to improve organizational efficiency through optimization of stakeholders relations. The theory argues that by increasing value for stakeholders then organizations will improve in all aspects (Freeman, 2010).

This theory offers guidance on how managers should function. The theory tries to urge managers to clearly articulate the mutual value they make, and what unites its primary stakeholders together. This will drive the organization forward and generates better performance. In addition, it thrusts managers to know how to conduct business especially, what types of connections they need to form with stakeholders while delivering their mandate. Managers need to inspire stakeholders, develop relations, and create societies where everybody strives to offer their greatest in delivering the value promised by the company. Employees are considered as stakeholders therefore when valued through further training by focusing on learning and growth perspective, then they will work harder and become more productive. This translates to greater employee retention, greater value to customers, increased productivity, and eventually better organizational performance. This theory instigates the second and fourth specific objectives.

\subsection{Institutional theory}

This theory is based on a socially constructed institutional environment and sees organizations like open systems. Therefore, the external environment, as well as actors within firms, help to shape organizational activities and structures (Scott, 2004). Organizations are viewed not to be autonomous agents that seek to maximize profit but survive within a social network of expectations and norms that shape and constrain managerial choice (Raynard, 2015). The theory helps to link an organization's actions and societal views. Management is conscious of social opinions and views and ready to integrate societal expectations and norms, regulations, requirements and rules in its day-to-day organizational operations (Scott, 2004). Therefore, the theory demonstrates the importance of focusing on internal business processes that conform to the societal norms and expectations for better organizational performance. This theory anchors the third specific objective. 
International Journal of Business Management, Entrepreneurship and Innovation, Volume 2, Issue 3, 2020, PP 102-113, ISSN 2707-8027

\section{IIJCAB}

\section{Conceptual Framework}

The organizational performance of $\mathrm{KNH}$ is the outcome variable and the predictor variables are the four BSC perspectives; customer focus, financial focus, internal business processes perspective and learning and growth. The influence of these predictor variables on the outcome variable is the core mandate of this study. Organizational performance as an outcome variable was measured using different indicators such as patient satisfaction, drug availability, increased revenue, reduction in mortality rates, patient based, operational cost, timeliness in service provision and medical equipment availability. Therefore, the study was guided by the following conceptual framework.

\section{Independent variables

\begin{tabular}{|cl|}
\hline Financial perspective Focus \\
- & revenue streams \\
& diversification \\
- & cost management \\
- & revenue generation \\
\hline
\end{tabular}

\section{Focus on Customer perspective}

- Quality services provision

- Responsiveness to patient's needs

- specialized services

\section{Focus on Internal business processes perspective \\ - length of hospital stay \\ - Patient safety \\ - Hospital acquired infections \\ - essential supplies}

\section{Focus on learning and growth perspective}

- new services

- Research conducted

- Professional misconduct

- Technology adoption
Dependent variable
Organizational performance

- Patient satisfaction

- Revenue collection

- Patients base

- Drug availability

- Cost reduction

- Equipment availability

- Timeliness in service provision

- Mortality rate

Figure 1: Conceptual Framework 
International Journal of Business Management, Entrepreneurship and Innovation, Volume 2, Issue 3, 2020, PP 102-113, ISSN 2707-8027

\section{IJCAB}

\section{Research Methodology}

The study adopted a descriptive study design with quantitative techniques. This study design was adopted to help get information from respondents on how balanced scorecard perspectives influence KNH's organizational performance. In this study the researcher targeted the management staff members of all functional departments at Kenyatta National Hospital which were eighty in total. According to the Kenyatta National Hospital organizational structure the management staff. The sample size was calculated based on Yamane 1967 formula (Israel, 1992) for sample size determination for proportions because the population was finite and the population size was known. Pre-tested closed-ended questionnaire was used for primary data collection from the management staff members. The questionnaire was the main data collection instrument. Questionnaires are accepted mode for collecting data because they are cost-effective and relative ease to administered and constructed (Mugenda and Mugenda 2003).

The study population was segregated into different strata depending on different departments and sections or units. From strata of deputy directors, head of departments and head of section/unit the study proportionately selected $85 \%$ of the target population in each stratum. From stratum of directors the study proportionately selected $50 \%$ of the target population. Then a pretested closeended questionnaire was given to the respondents by the researcher after they signed the informed consent form. Data collection was by self-administering of the questionnaires. Any clarification and assistant by the respondents were provided by the researcher. After data collection, each study participant was appreciated by the researcher. Data was coded into SPSS and statistical analysis was done using SPSS version 23. All the variables were put on multiple regression analysis model. A multiple regression analysis is a statistical technique used to establish a linear correlation between two or more variables hence it shows the variability among the variable under study.

\section{Inferential Statistics}

To determine the relationship of each balanced scorecard perspective on organizational performance a correlation test was done on each perspective and the results are shown in table 1 below.

Table 1: Correlation

\begin{tabular}{|ll|r|r|r|r|r|}
\hline & & $\begin{array}{c}\text { Customer } \\
\text { Perspective }\end{array}$ & $\begin{array}{c}\text { Financial } \\
\text { Perspecti } \\
\text { ve }\end{array}$ & $\begin{array}{c}\text { Internal } \\
\text { Business } \\
\text { Process }\end{array}$ & $\begin{array}{c}\text { Learning \& } \\
\text { Growth }\end{array}$ & $\begin{array}{c}\text { Organizati } \\
\text { onal } \\
\text { Performan } \\
\text { ce }\end{array}$ \\
\hline Customer & Pearson & 1 & $.648^{* *}$ & $.874^{* *}$ & $.702^{* *}$ & $.750^{* *}$ \\
Perspective & Correlation & & .000 & .000 & .000 & .000 \\
& Sig. (2-tailed) & $\mathrm{N}$ & 67 & 67 & 67 & 67 \\
\hline Financial & Pearson & $.648^{* *}$ & 1 & $.658^{* *}$ & $.502^{* *}$ & $.608^{* *}$ \\
Perspective & Correlation & .000 & & .000 & .000 & .000 \\
& Sig. (2-tailed) & 67 & 67 & 67 & 67 & 67 \\
\hline Internal Business & Pearson & $.874^{* *}$ & $.658^{* *}$ & 1 & $.762^{* *}$ & $.645^{* *}$ \\
Process & Correlation & .000 & .000 & & .000 & .000
\end{tabular}


International Journal of Business Management, Entrepreneurship and Innovation, Volume 2, Issue 3, 2020, PP 102-113, ISSN 2707-8027

\begin{tabular}{|c|c|c|c|c|c|c|}
\hline & & $\begin{array}{c}\text { Customer } \\
\text { Perspective }\end{array}$ & $\begin{array}{c}\text { Financial } \\
\text { Perspecti } \\
\text { ve }\end{array}$ & $\begin{array}{l}\text { Internal } \\
\text { Business } \\
\text { Process }\end{array}$ & $\begin{array}{c}\text { Learning \& } \\
\text { Growth }\end{array}$ & $\begin{array}{l}\text { Organizati } \\
\text { onal } \\
\text { Performan } \\
\text { ce }\end{array}$ \\
\hline & $\mathrm{N}$ & 67 & 67 & 67 & 67 & 67 \\
\hline $\begin{array}{l}\text { Learning \& } \\
\text { Growth }\end{array}$ & $\begin{array}{l}\text { Pearson } \\
\text { Correlation } \\
\text { Sig. (2-tailed) } \\
\mathrm{N} \\
\end{array}$ & $\begin{array}{r}.702^{* *} \\
.000 \\
67 \\
\end{array}$ & $\begin{array}{r}.502^{* *} \\
.000 \\
67 \\
\end{array}$ & $\begin{array}{r}.762^{* *} \\
.000 \\
67 \\
\end{array}$ & $\begin{array}{r}1 \\
67 \\
\end{array}$ & $\begin{array}{r}.542^{* *} \\
.000 \\
67 \\
\end{array}$ \\
\hline $\begin{array}{l}\text { Organizational } \\
\text { Performance }\end{array}$ & $\begin{array}{l}\text { Pearson } \\
\text { Correlation } \\
\text { Sig. (2-tailed) } \\
\text { N }\end{array}$ & $\begin{array}{r}.750^{* *} \\
.000 \\
67\end{array}$ & $\begin{array}{r}.608^{* *} \\
.000 \\
67\end{array}$ & $\begin{array}{r}.645^{* *} \\
.000 \\
67\end{array}$ & $\begin{array}{r}.542^{* *} \\
.000 \\
67\end{array}$ & 67 \\
\hline
\end{tabular}

**. Correlation is significant at the 0.01 level (2-tailed).

Source: Field data, (2020)

A positive relationship between focus on financial perspective and organizational performance was established with a moderate correlation co-efficient of 0.608. An R squared of 0.369 which indicated that $37 \%$ of the variances in organizational performance at $\mathrm{KNH}$ were explained by the variances in financial perspectives. This finding collates with Marete, (2015) findings on institution of higher learning. It was established that there was a strong positive correlation of 0.75 between focus on customer perspective and organizational performance. This finding replicates previous findings by Seth A, (2013) and Marete, (2015). An R squared of 0.562 which implied that focusing on customer perspective contributed up to $56.2 \%$ of organizational performance. There was a moderated positive correlation of 0.65 between focus on internal business processes perspective and organizational performance. An R squared of 0.416 which implied that focusing on internal business processes perspective contributed up to $41.6 \%$ of organizational performance. The study found a positive relationship between focus on learning and growth perspective and organizational performance with a moderate correlation of 0.54 . An R squared of 0.293 which indicated that focusing on learning and growth perspective contributed up to $29.3 \%$ of organizational performance.

To determine the influence of all the balanced scorecard perspectives on organizational performance, a multiple linear regression was conducted.

Table 2: Model Summary for Multiple Regression Analysis

\begin{tabular}{ccccc} 
Model & $\mathrm{R}$ & R Square & Adjusted R Square & $\begin{array}{c}\text { Std. Error of the } \\
\text { Estimate }\end{array}$ \\
\hline 1 & $.770^{\mathrm{a}}$ & .593 & .566 & 4.202 \\
\hline
\end{tabular}

a. Predictors: (Constant), Learning and growth perspective, Financial perspective, Customer perspective, Internal business process perspective

Source: Field data, (2020) 
International Journal of Business Management, Entrepreneurship and Innovation, Volume 2, Issue 3, 2020, PP 102-113, ISSN 2707-8027

[IJCAB

Table 3: Coefficients for Multiple Regression Analysis

\begin{tabular}{lcccccc} 
& \multicolumn{2}{c}{$\begin{array}{c}\text { Unstandardized } \\
\text { Coefficients }\end{array}$} & $\begin{array}{c}\text { Standardized } \\
\text { Coefficients }\end{array}$ & & \\
\cline { 2 - 5 } Perspectives & $\mathrm{B}$ & Std. Error & Beta & t & Sig. \\
\hline (Constant) & 3.531 & 3.491 & & 1.011 & .316 \\
Customer & 1.363 & .331 & .705 & 4.117 & .000 \\
Financial & .402 & .190 & .232 & 2.110 & .039 \\
Internal Business process & .360 & .409 & .167 & .879 & .383 \\
& & & & & \\
Learning and Growth & .117 & .259 & .057 & .453 & .652
\end{tabular}

a. Dependent Variable: Organizational Performance

Source: Field data, (2020)

These results show that financial perspective and customer perspectives focus were statistically significant predictor of organizational performance at $(\mathrm{p}<0.05)$ while internal business process and learning and growth were not statistically significant when regressed together. An R squared of 0.593 which implied that focusing on all of the balanced scorecard perspectives contributed up to $59.3 \%$ of organizational performance. Meaning there is a positive relationship between the balanced scorecard perspectives and organizational performance financial perspective and customer perspectives being statistically significant. These findings vary with those of Seth A, (2013) and Marete, (2015) who found that all the balanced scorecard perspectives were statistically significant in predicting organizational performance.

\section{Conclusion}

From this study it is evident the balanced scorecard can be used as a strategic management tool in public facilities and not only as a measurement tool. The study concludes that focus on financial perspective contributes significantly to performance of an organization. Therefore, an organization that puts more focus on its financial aspect could record excellent organizational performance. Based on the research findings the study concludes that focus on customer perspective significantly influences the performance of an organizations. An organization that takes into consideration its customers it could record better performance. The study drew conclusion that there is a moderate positive correlation between focus on internal business process perspective and organizational performance. Therefore, an organization that puts more focus on its internal business processes could improve its performance. The research further concludes that there is a moderate positive correlation between focus on learning and growth perspective and organizational performance. Therefore, an organization that puts more focus on its learning and growth could improve its overall organizational performance.

\section{Recommendations}

The study recommends that $\mathrm{KNH}$ should continue using the balanced scorecard and other public hospitals or institutions should also adopt it. The continuous usage and new adoption of the balanced scorecard would ensure better organizational performance. 
International Journal of Business Management, Entrepreneurship and Innovation, Volume 2, Issue 3, 2020, PP 102-113, ISSN 2707-8027

[IJCAB

The study results showed a positive influence of financial perspective focus and organizational performance. This significantly implies the need for more application of financial goals within $\mathrm{KNH}$. The management of $\mathrm{KNH}$ should therefore, focus more on its finances through diversification of revenue streams, implementation of cost management strategies, improving financial accountability and transparency. On customer perspective the study found a significant positive relationship on performance. Therefore, the study recommends that $\mathrm{KNH}$ should focus more on its patients to improve its organizational performance. This can be done through offering of quality services, responding quickly to patients needs and offering more specialists services. The study recommends more focus on hospital's internal business process to improve efficiency and ultimately better organizational performance. The study recommends more focus on hospital's learning and growth through training of more staff, adopt new technologies, become innovative and conduct more research. This will ultimately improve organizational performance.

\section{References}

abu-Jarad, I. Y., Yusof, N., \& Nikbin, D. (2010). A Review Paper On Organizational Culture And Organizational Performance. International Journal Of Business And Social Science, 1(3), 26-46. Https://Doi.Org/10.1108/01443570610710579

Barney, J. B. (1996). The Resource-Based Theory Of The Firm, (September 2015).

Behrouzi, F., Shaharoun, A. M., \& Ma'aram, A. (2014). Applications Of The Balanced Scorecard For Strategic Management And Performance Measurement In The Health Sector. Australian Health Review, 38(2), 208-217. Https://Doi.Org/10.1071/Ah13170

Bobe, B. J., Mihret, D. G., \& Obo, D. D. (2017). Public-Sector Reforms And Balanced Scorecard Adoption: An Ethiopian Case Study. Accounting, Auditing \& Accountability $\quad$ Journal, 00 . Https://Doi.Org/10.1108/Aaaj-03-2016-2484

Chimtengo, Stephen, K. M. And R. H. (2017). An Evaluation Of Performance Using The Balanced Scorecard Model For The University Of Malawi's Polytechnic. African Journal Of Business Management, 11(4), 84-93. Https://Doi.Org/10.5897/Ajbm2016.8201

Chimwani, P. M., Nyamwange, O., \& Robert, O. (2013). Application Of Strategic Performance Measures In Small And Medium-Size Manufacturing Enterprises In Kenya:The Use Of The Balanced Scorecard Perspectives, 2(6), 45-60.

Daft, R. L. (2008). Organization Theory And Design, Tenth Edition.

Donald R. Cooper, P. S. S. (2011). Business Research Methods (11th, Illust Ed.). Mcgraw-Hill/Irwin, 2011.

Freeman, R. E. (2010). Strategic Management: A Stakeholder Approach. Cambridge University Press, 2010.

Gacheri, M. (2011). Effects Of Balanced Scorecard Performance Management System On Employee Job Satisfaction At The Co-Operative Bank Of Kenya Ltd, (November).

George, D. And Mallery, P. (2003). No Titlespss For Windows Step By Step: A Simple Guide And Reference. Boston: Allyn And Bacon. 
International Journal of Business Management, Entrepreneurship and Innovation, Volume 2, Issue 3, 2020, PP 102-113, ISSN 2707-8027

[IJCAB

Gonzalez-Sanchez, M. B., Broccardo, L., \& Martins Pires, A. M. (2017). The Use And Design Of The Bsc In The Health Care Sector: A Systematic Literature Review For Italy, Spain, And Portugal. The International Journal Of Health Planning And Management, (September 2016), 1-25. Https://Doi.Org/10.1002/Hpm.2415

Gumbus, A. (2005). Introducing The Balanced Scorecard: Creating Metrics To Measure Performance. Journal Of Management Education, 29(4), 617630. Https://Doi.Org/10.1177/1052562905276278

Gurd, B., \& Gao, T. (2007). Lives In The Balance: An Analysis Of The Balanced Scorecard (Bsc) In Healthcare Organizations. International Journal Of Productivity And Performance Management, 57(1), 6-21. Https://Doi.Org/10.1108/17410400810841209

Harrison, J. S., \& Wicks, A. C. (2017). Stakeholder Theory, Value, And Firm Performance, $\quad$ l(January 2013), 97-124. Https://Doi.Org/10.5840/Beq20132314

Hasan, R. U., \& Chyi, T. M. (2017). Practical Application Of Balanced Scorecard - A Literature Review. Journal Of Strategy And Performance $\begin{array}{lrr}\text { Management, } & 5(3), & \text { R7-103. }\end{array}$

Https://Search.Proquest.Com/Docview/1947431383?Accountid=26636\%

0ahttp://Link.Periodicos.Capes.Gov.Br/Sfxlcl41?Url_Ver=Z39.88-

2004\&Rft_Val_Fmt=Info:Ofi/Fmt:Kev:Mtx:Journal\&Genre=Article\&Si

$\mathrm{d}=$ Proq:Proq\%3amaterialscienceengineering\&Atitle=Practical+Applicati

o

Hussey, D. (2002). Company Analysis: Determining Strategic Capability, 52, 43-52. Https://Doi.Org/10.1002/Jsc.568

Israel, G. D. (1992). Determining Sample Size. University Of Florida.

Javier, P. E. And S. (2002). Last Bank Standing: What Do I Gain If You Fail? European Economic Review,Elsevier, Vol. 46(9), Pages 1599-1622, October.

Kairu, E. W., Wafula, M. O., Okaka, O., Odera, O., \& Akerele, E. K. (2013). Effects Of Balanced Scorecard On Performance Of Firms In The Service Sector. European Journal Of Business And Management, 5(9), 81-88. Retrieved Http://Www.Iiste.Org/Journals/Index.Php/Ejbm/Article/View/5127

Kaplan, R. S., \& Norton, D. P. (1992). The Balanced Scorecard- Measures That Drive Performance. Harvad Business Review, P71-79.

Kaplan, R. S., \& Norton, D. P. (1996). Using The Balanced Scorecard As A Strategic Management $\quad$ System, $14 . \quad$ Https://Doi.Org/10.1016/S08404704(10)60668-0

Khaunya, M. F., Wawire, B. P., \& Chepng, V. (2015). Devolved Governance In Kenya; Is It A False Start In Democratic Decentralization For Development ?, 4(1), 27-37.

Lin, Z., Yu, Z., \& Zhang, L. (2014). Performance Outcomes Of Balanced Scorecard Application In Hospital Administration In China. China Economic Review, 30, 1-15. Https://Doi.Org/10.1016/J.Chieco.2014.05.003 
International Journal of Business Management, Entrepreneurship and Innovation, Volume 2, Issue 3, 2020, PP 102-113, ISSN 2707-8027

[i]CAB

Marete, J. K. (2015). Influence Of Balanced Scorecard On Organizational Performance In Institutions Of Higher Learning: A Case Study Of University Of Nairobi And Centre For Mathematics, Science And Technology Education In Africa. European Journal Of Business And Managementonline), $\quad 7(20), \quad 2222-2839 . \quad$ Retrieved $\quad$ From Http://Www.Iiste.Org/Journals/Index.Php/Ejbm/Article/Viewfile/23836/2 4407

Maureen, E., \& Daniel, M. (2014). The Influence Of Customer Centric Strategic Approach For Competitive Advantage On Customer Satisfaction In Cfc Stanbic Bank Kenya Limited, Ii(11), 1-21.

Mitroff, I. (1984). Stakeholders Of The Oqpnhtional Mind, 23(4), 428-433.

Mugenda M. O., \& M. A. G. (2003). Research Methods: Quantitative \& Qualitative Approaches. African Centre For Technology Studies.

Mumbi, J. W. (2015). The Balanced Scorecard And The Employee Performance At Britam Jane Wanjiru Mumbi A Research Project Submitted In Partial Fulfillment Of The Requirements For The Award Of The Degree Of Master Of Business Administration School Of Business , University Of $\mathrm{Na}$.

Musyoki, R. (2015). The Role Of Balanced Score Card As A Strategic Management Tool At Kenya Ports Authority, Mombasa, Kenya. International Journal of Scientific And Research Publications, 5(11), 240-244. Retrieved From Http://Www.Ijsrp.Org/Research-Paper1115//jsrp-P4737.Pdf

Mutai, H. C. (2019). Application Of Balanced Scorecard On Organizational Performance In Selected Public Secondary Schools In Partial Fulfilment Of The Requirements For The Degree Of Master Of Business Administration ( Strategic Management.

Muthoni, P. (2018). Non-Financial Balanced Scorecard Perspectives And Service Quality In Commercial Banks In Thika Town, Kenya.

Ondieki, E. M. (2017). The Effect Of The Balanced Scorecard On Organizational Performance In The Public Sector In Kenya: A Case Of Kenya Bureau Of Standards By United States International University. Unpublished Masters Thesis, United States International University.

Pierre J. Richard, Timothy M. Devinney, G. S. Y. And G. J. (2009). Measuring Organizational Performance: Towards Methodological Best Practice. Journal Of Management, Vol. 35 No. 3,

Rigby, D. K. (2015). Management Tools 2015: An Executive's Guide. Bain \& Company, 1-68. Https://Doi.Org/Article

Rigby, D. K., \& Bilodeau, B. (2011). Management Tools And Trends 2011. Bain And Company, Inc. Retrieved From Http://Www.Bain.Com

Seth A., \& Oyugi L. (2013). Influence Of Balanced Scorecard On Organizational Performance, 1(8), 1-12.

Susan, O. (2014). Gender Inequality, Financial Development And Economic Growth In Kenya. African Journal Of Education, Science And Technology, 1(4), 208-216.

Taticchi, P., Tonelli, F., \& Cagnazzo, L. (2010). Performance Measurement 
International Journal of Business Management, Entrepreneurship and Innovation, Volume 2, Issue 3, 2020, PP 102-113, ISSN 2707-8027

[i]CAB

\begin{tabular}{|c|c|c|c|}
\hline $\begin{array}{l}\text { And Mana } \\
\text { Measuring }\end{array}$ & A Literature & $\begin{array}{l}\text { Review And } \\
\text { Excellence. }\end{array}$ & \\
\hline
\end{tabular}

Https://Doi.Org/10.1108/13683041011027418

Wambui, M. F. (2013). Determinants Of Self Directed Referral Amongst Patiets Seeking Health Services At Kenyatta National Hospital, Nairobi, Kenya. Unpublished Masters Thesis, University Of Nairobi.

Wernerfelt, B. (1984). A Resource-Based View Of The Firm, 5(April 1983), $171-180$.

Yaghoobi, T., \& Haddadi, F. (2016). Organizational Performance Measurement By A Framework Integrating Bsc And Ahp. International Journal Of Productivity And Performance Management, 65(7), 959-976. Https://Doi.Org/10.1108/Ljppm-01-2015-0001

Yongvanich, K., \& Guthrie, J. (2009). Balanced Scorecard Practices Amongst Thai Companies: Performance Effects. Pacific Accounting Review, 21(2), 132-149. Https://Doi.Org/10.1108/01140580911002062

Zelman, W. N., Pink, G. H., \& Matthias, C. B. (2003). Use Of The Balanced Scorecard In Health Care. Journal Of Health Care Finance, 29(4), 1-16.

This is an open-access article published and distributed under the terms and conditions of

the (c) (i) \&) Creative Commons Attribution 4.0 International License of United States unless otherwise stated. Access, citation and distribution of this article is allowed with full recognition of the authors and the source. Authors seeking to publish with an Internationally Peer Reviewed Journals should consider https://www.ijcab.org/ by writing to the Editor at editor@ijcab.org or submitting online at https://journals.ijcab.org/journals/index.php. The articles must be quality and meet originality test. 